\title{
ダムブレイク型造波による砂丘の 津波越流実験と数値計算
}

\author{
二階堂 竜司 1 - 青木 伸一 2 - 荒木 進歩 3 - 常田 賢一 $4 \cdot M_{U H A J J R}{ }^{5}$ \\ 1正会員（株）建設技術研究所 東京本社河川部海岸海洋室（テ330-0071 埼玉県さいたま市浦和区上木崎1-14-6） \\ E-mail:nikaidou@ctie.co.jp \\ $2 フ$ エロー会員 大阪大学大学院教授 工学研究科（广565-0871 大阪府吹田市山田丘2-1) \\ E-mail: aoki@civil.eng.osaka-u.ac.jp \\ 3 正会員 大阪大学大学院准教授 工学研究科（广565-0871 大阪府吹田市山田丘2-1） \\ E-mail: araki@civil.eng.osaka-u.ac.jp \\ 4フェロー会員 大阪大学大学院教授 工学研究科 (T565-0871 大阪府吹田市山田丘2-1) \\ E-mail: tokida@civil.eng.osaka-u.ac.jp \\ 5 大阪大学大学院 工学研究科 ( $\bar{T} 565-0871$ 大阪府吹田市山田丘2-1) \\ E-mail: ajier12@gmail.com
}

\begin{abstract}
本研究は, 津波越流による砂丘の侵食実態および砂丘侵食への津波移動床計算の適用性を検討寸るため, ダムブレイク型造波による砂丘の侵食実験とその再現計算を行った。侵食実験では，津波の流況によって 堤体の侵食位置が異なり, 越流初期は表側から裏法が侵食し, 時間が経過すれば主に裏側が侵食される傾 向にあった，再現計算では堤体表側の侵食の再現性に課題があるものの，適切なパラメータの設定により 堤体の侵食面積は概衩再現できるように調整できた. また, 中田島砂丘周辺を対象として南海トラフの巨 大地震が発生した場合の数值計算を行った結果, 津波越流により砂丘は大きく侵食が生じるものの, 堤体 の幅が大きいものはは耐侵食性を有することが確認できた.
\end{abstract}

Key Words : tsunami, dune, overflow, sediment transport, hydraulic model test, numerical simulation

\section{1. はじめに}

砂丘は，津波に対して背後地への浸水被害の軽減など の効果を有している．例えば，前川ら ${ }^{11} は ， 2011$ 年東北 地方太平洋沖地震津波後に, 砂丘あり・なしの背後の浸 水深や家屋被害状況を調査し, 砂丘が存在することによ る津波減勢効果を明らかにした。 しかし，津波越流時に は砂丘の侵食および破堤が生じる恐れがある，砂丘の持 つ減勢効果を把握し，津波減災地域づくり等に役立てる ためには，時系列の侵食の予測手法を確立寸る必要があ る. 国や自治体で害施されている津波浸水被害シミュレ ーションの砂丘の取り扱いにおいても，時系列の砂丘の 侵食は評価されていない場合がほとんどであり，精度の 高い津波浸水被害の算定および砂丘等の持つ減勢効果の 評価が望まれる。

砂丘の侵食に関する既往研究としては，例えば，柳沢

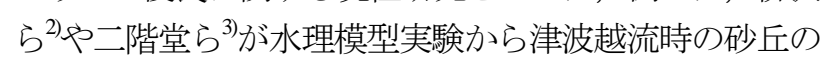
侵食実態を分析しているが，地形変化を考慮した数值シ ミュレーションの検討には至っていない.

津波移動床計算の既往研究事例では, 湾や港内の適用
事例が多く，起伏のある地形への適用事例は少ない，山 下ら ${ }^{4}$ が陸前高田市の高田松原, 今井ら 5 $^{5}$ 北上川の河口 砂州, 下園らの゙実験の砂堆（砂丘）に対する地形変化 を検討した事例がある程度である．津波移動床計算の砂 移動量の算定式は, 平坦地形の実験で実施されているこ とから，砂丘のような起伏のある地形への適用性につい て検討する必要がある.

本研究は, ダムブレイク型造波による砂丘の津波越流 実験を行い, 津波越流時の砂丘の侵食実態の把握を行う. 次に, 数值シミュレーションから実験での砂丘の侵食状 況の再現計算を行い, 津波移動床計算を砂丘の侵食に適 用した場合の適用性を検討する。また，構築した数值計 算モデルを中田島砂丘沿岸に適用し，津波越流による砂 丘の侵食量の試算, 侵食特性の把握を行うものである.

\section{2. 砂丘の津波越流実験}

\section{(1) 実験水路の概要}

本研究で用いた実験水路は, 大阪大学の屋外にある長 さ $44.0 \mathrm{~m}$, 幅 $0.7 \mathrm{~m}$, 高さ $1.2 \mathrm{~m}$ 断面二次元水路であり, 


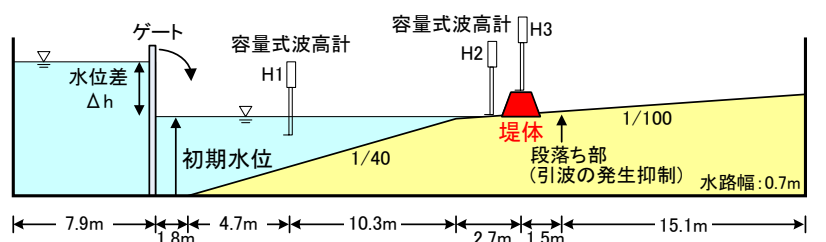

図-1 実験水路の模式図

その模式図を図-1に示す，砂丘は砂で台形状に形成し， 1/100勾配の陸上区間に設置した.

ダムブレイクによる造波は，ゲート沖側と岸側で水位 差を設け，ゲートを岸側に倒伏して急開寸ることで，段 波状の津波を発生させた. 堤体越流後に津波が引き波と して斜面を逆流しないように，堤体背後に斜面のべニヤ 板を撤去した段落ち部を設けた。

ゲートの沖側・岸側の水位差は，ゲート付近にメジャ 一を設置し，目視で読み取った。発生させた津波水位は， 沖側（H1），堤体の法先（H2），堤体の天端（H3）に 設置した3か所の容量式波高計より計測した.

時系列の堤体形状は，透明な観測面をビデオカメラで 撮影し, 岸沖方向距離 $0.5 \mathrm{~cm}$ 間隔で 1 秒間隔にデジタイ ズすることで把握した.

\section{(2) 実験ケースおよび堤体形状}

実験ケース一覧を表-1 に示寸，堤体の高さは全て 8 $\mathrm{cm}$ とし，堤体幅および津波外力（ゲートの沖側・岸側 の水位差, 初期水位) を変化させた.

実験に使用した砂の中央粒径は $0.15 \mathrm{~mm}$ （シルト・粘 土分3 \%) の砂質土である. 堤体の含水比は最適含水比 (5.3\%)とし, 締固め度は最適含水比時の 90 \%になるよう に調整した.

\section{（3）津波越流時の津波の挙動と砂丘の侵食実態}

表-1のケース3を例として，津波越流時の容量式波高 計の計測水位およびビデオカメラの越流時の写真を図-2 に示寸．津波が堤体を越流した初期の段階（図-2のc) では，堤体表法の水深が小さく堤体の表側・裏側ともに 射流として越流しており，堤体の侵食は表側および裏側 で生じている，津波が越流し一定時間が経過（図-2の d) すると, 堤体表側の水深が大きくなり堤体表側の流 れが常流へと変化し始める. この時, 堤体天端 $(\mathrm{H} 3)$

表-1 実験ケース一覧

\begin{tabular}{c|c|c|c|c|c}
\hline No & 堤体高 & 天端幅 & $\begin{array}{c}\text { 法勾配 } \\
\text { (表法·裏法) }\end{array}$ & $\begin{array}{c}\text { 水位差 } \\
\Delta \mathrm{h}\end{array}$ & $\begin{array}{c}\text { 初期水位 } \\
\text { (水路床基準) }\end{array}$ \\
\hline 1 & $8 \mathrm{~cm}$ & $8 \mathrm{~cm}$ & $1: 2$ & $20 \mathrm{~cm}$ & $43.5 \mathrm{~cm}$ \\
\hline 2 & $8 \mathrm{~cm}$ & $8 \mathrm{~cm}$ & $1: 2$ & $30 \mathrm{~cm}$ & $41.0 \mathrm{~cm}$ \\
\hline 3 & $8 \mathrm{~cm}$ & $8 \mathrm{~cm}$ & $1: 2$ & $40 \mathrm{~cm}$ & $40.0 \mathrm{~cm}$ \\
\hline 4 & $8 \mathrm{~cm}$ & $8 \mathrm{~cm}$ & $1: 2$ & $50 \mathrm{~cm}$ & $38.0 \mathrm{~cm}$ \\
\hline 5 & $8 \mathrm{~cm}$ & $8 \mathrm{~cm}$ & $1: 2$ & $60 \mathrm{~cm}$ & $35.5 \mathrm{~cm}$ \\
\hline 6 & $8 \mathrm{~cm}$ & $16 \mathrm{~cm}$ & $1: 2$ & $20 \mathrm{~cm}$ & $43.5 \mathrm{~cm}$ \\
\hline 7 & $8 \mathrm{~cm}$ & $16 \mathrm{~cm}$ & $1: 2$ & $30 \mathrm{~cm}$ & $41.5 \mathrm{~cm}$ \\
\hline 8 & $8 \mathrm{~cm}$ & $16 \mathrm{~cm}$ & $1: 2$ & $40 \mathrm{~cm}$ & $40.0 \mathrm{~cm}$ \\
\hline 9 & $8 \mathrm{~cm}$ & $16 \mathrm{~cm}$ & $1: 2$ & $50 \mathrm{~cm}$ & $38.0 \mathrm{~cm}$ \\
\hline
\end{tabular}
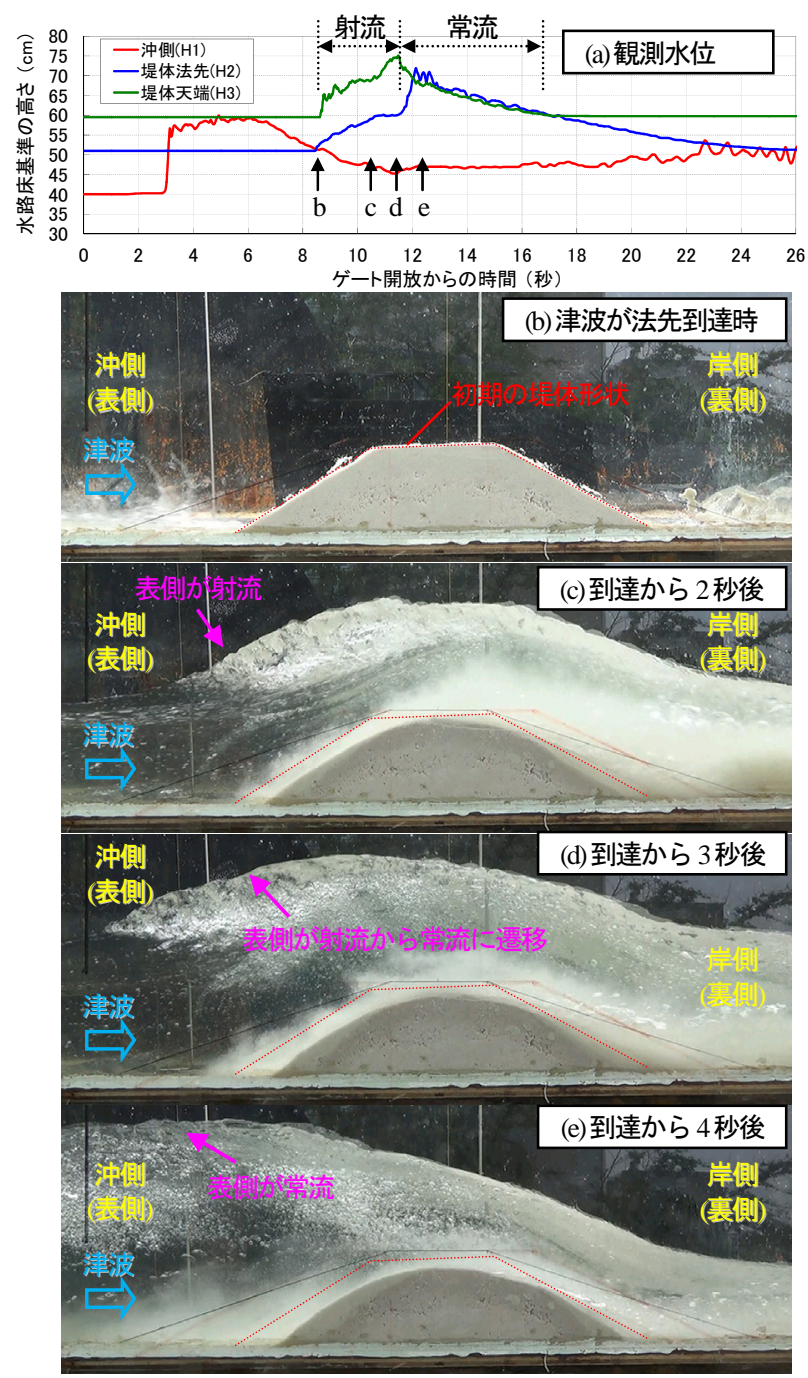

図-2 時系列の計測水位と堤体写真（ケース 3 の例）

で最も津波水位が高くなる，その後（図-2のe）は，堤 体表側が常流のまま津波越流が生じる.

このことから，津波越流時には，特に裏法側の高流速 およびそれに伴う侵食に着目されることが多いが，越流 初期の時間は堤体表側においても津波が射流となるため, 堤体表側も侵食が生じることがわかった．ただし，本実 験の堤体の砂はシルト・粘土分が3\%で砂分が卓越する が，常田らかのようにシルト・粘土分を多く含む盛土の 場合は，耐侵食性が大きく難浸透性であるため，堤体の 侵食は小さくなる．植生で被覆されている場合も植生の 而骎食性から侵食が軽減されると考えられる.

ここで，堤体の侵食特性を把握するため，堤体の地形 変化量から式(1)より漂砂量 $q(x)$ を算定し, その結果を図一 3に示した.

$$
q(x)=-(1-\lambda) \int_{0}^{x} \frac{\partial z}{\partial t} d x+q(0)
$$

ここに, $t$ : 時間, $x$ : 岸沖方向距離, $\mathrm{z}$ : 基準面からの 堤体高さ, $\lambda$ : 砂の空隙率 $(=0.4), q$ : 単位幅あたりの全 漂砂量 $(q(0)$ は $x=0$ 地点の $q$ であり0) である.

漂砂量 $q(x)$ の傾きが右肩上がりに変化すれば地形が侵 
(a) 時系列の堤体の侵食状況

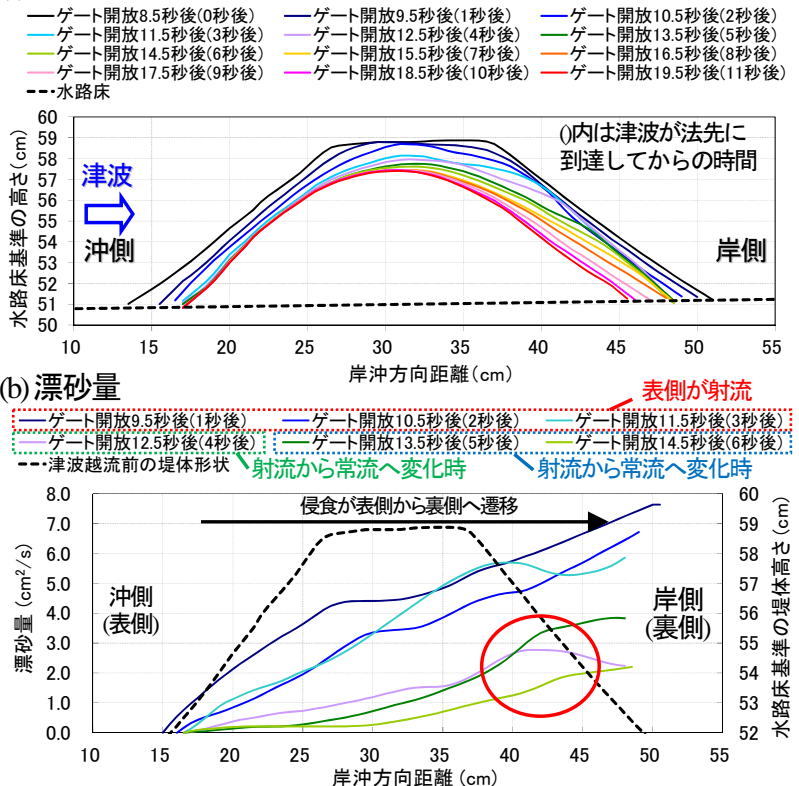

図-3 時系列の堤体の侵食状況との漂砂量（ケース 3 )

食されることを表しており，津波が法先到達から1〜3 秒は表側の流れが射流のため，表法から裏面まで全体的 に侵食しているうえ，漂砂量（砂の移動量）が大きい. 一方，表側の流れが射流から常流へ変化する4秒以降

（図-3(b)の赤丸）では侵食位置が主に裏側であり，漂 砂量（砂の移動量）が小さいことがわかる．堤体表側の 津波の流れが射流から常流へ変化するに伴い，地形の侵 食位置が表側から裏側に遷移し，侵食量も小さくなる様 子が確認できた.

\section{(4) 天端高さの侵食速度}

シールズ数や摩擦速度と比べて直接的に計測しやすい 物理量の越流水深を用いて，侵食実験から把握した各ケ 一スの地形変化量から，天端高さの侵食速度の算定を試 みる. 砂の侵食速度は, 式(2)のようにシールズ数の累 乗で表現されることが多い.

$$
E=\alpha_{0}\left(\tau-\tau_{\mathrm{c}}\right)^{\gamma_{0}}
$$

ここに，E: 侵食速度， $\tau$ : シールズ数， $\tau_{c}$ : 限界シー ルズ数, $\alpha_{0}, \gamma_{0}:$ 定数である.

シールズ数は式(3)より摩擦速度の2乗，摩擦速度は例 えば式(4)の対数則より流速と同次元で表現される.

$$
\begin{aligned}
\tau & =u_{*}^{2} / \mathrm{sgd} \\
\frac{u_{*}}{u} & =\frac{\kappa}{\ln \left(h / z_{0}\right)-1}
\end{aligned}
$$

ここに, $s$ : 砂の水中比重, $g:$ 重力加速度, $d:$ 砂の 粒径, $u$ : 平均流速, $\kappa$ : カルマン定数 $(=0.4), h:$ 水深, $z_{0}:$ 粗度高さである.

ここで，限界水深 $h c か ゙$ 邵ら ${ }^{8)}$ のように堤体の天端上で 生じると仮定すれば，限界水深を越流水深とみなせ，式

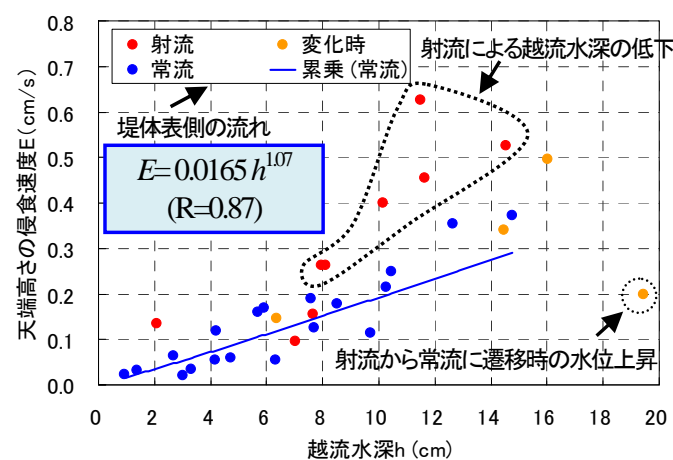

図-4 天端高さの侵食速度と越流水深の関係（ケース 1～5）

(5)より限界水深の $1 / 2$ 乗で流速が算出される. 式(3) (5) より，シールズ数 $\tau$ は越流水深 $h$ （=限界水深 $h c ）$ の1乗 で表現できるため，侵食速度Eは式(2)から式(6)の形に変 形した.

$$
\begin{aligned}
& u=\sqrt{g h_{c}} \approx \sqrt{g h} \\
& E=\alpha h^{\gamma}
\end{aligned}
$$

ここに, $h_{c}$ : 限界水深, $h:$ 越流水深， $\alpha, \gamma$ : 定数である. 上記を踏まえ，天端高さの侵食速度 $E$ （堤体の堤頂部 の高さが単位時間あたりに低下する高さ）と越流水深 $h$

（天端中央の容量式波高計設置地点H3）について累乗 で表現した結果を図-4に示す，この際，表側の流れを射 流，射流から常流一変化している時，常流の3つの分類 し，常流の場合について相関式を算出した．越流水深の 増加とともに侵食速度が増加する様子が見て取れ，その 相関係数 Rは0.87である.

侵食速度と越流水深の関係にばらつきがある要因は, 式(6)の条件は天端上で限界水深の発生を仮定したもの であるため，表側の津波は常流となっている必要がある。 表法の流れが射流の場合は，天端上で限界水深が発生せ ず，越流水深が過小になっていると考えられるため，相 関式よりも越流水深が小さく（図-4上で左側）プロット されている，一方，表法の流れが射流から常流に変化す る場合は，図-2で示したように天端上で一時的に水位が 増大寸るため，越流水深が大きく（図-4上で右側）プロ ットされている.

本実験は，津波外力，堤体の形状，砂の粒径など限ら れた条件において侵食速度を算定したものであるが，外 力に越流水深を用いて堤体の侵食速度を表現できる可能 性を示唆できた.

\section{3. 津波越流実験の再現計算}

\section{(1) 計算手法および基礎方程式}

\section{a) 津波の流動}

津波の流動は，以降の4。で現地海岸へ適用することを 念頭に置き, 広域への適用が可能な平面二次元非線形長 波理論を基礎方程式とした. 
表-2 再現計算における計算条件一覧

\begin{tabular}{|c|c|c|}
\hline 項目 & 設定 & 備考 \\
\hline $\begin{array}{l}\text { 入射波形 } \\
\text { (沖側境界) }\end{array}$ & $\begin{array}{l}\text { 容量式波高計(H1) } \\
\text { の観測水位 }\end{array}$ & $\begin{array}{l}\text { 水位のみを境界条件と } \\
\text { してえ, 流速は長波 } \\
\text { 近似で運動方程式より } \\
\text { 算定 }\end{array}$ \\
\hline 格子間隔 & $0.5 \mathrm{~cm}$ & \\
\hline 計算時間間隔 & 0.00005 秒 & \\
\hline $\begin{array}{l}\text { マニングの } \\
\text { 粗度係数 }\end{array}$ & \begin{tabular}{|l|} 
砂の堤体 : 0.015 \\
水路部 : 0.012 (固定 \\
床計算で同定)
\end{tabular} & $\begin{array}{l}\text { 瑅体の粗度は, 土木 } \\
\text { 学会水理委員会 }{ }^{0} \text { を参 } \\
\text { 考に再現計算より同定 }\end{array}$ \\
\hline 砂の粒径 & $0.15 \mathrm{~mm}$ (中央粒径) & 粒度分析結果 \\
\hline 砂の密度 & $2,500 \mathrm{~kg} / \mathrm{m} 3$ & 想定值 \\
\hline 巻き上げ量の定数 $a$ & 0.15 & 池野ら ${ }^{99}$ 推奨值 \\
\hline 鉛直拡散係数 $k z$ & 0.5 & $\begin{array}{l}\text { 池野ら9)の } 0.2 \mathrm{~mm} \text { の場合 } \\
\text { と同等とした }\end{array}$ \\
\hline
\end{tabular}

\section{b) 砂（掃流砂 · 浮遊砂）の移動}

津波移動床計算は，任意の粒径に応じた砂移動量が提 案されている池野ら の)の方法を用いた。基礎式は紙面の 都合で割愛するため，詳細は参考文献に記載の元論文を 参照いただきたい.

\section{(2) 計算条件}

計算条件一覧を表-2に示す．飽和浮遊砂濃度の設定は， 今井ら ${ }^{5}$ による流況に可変值と一定值(3\%とした)の大き い方を採用するものとした．移動床計算の前に予備計算 として，砂の堤体を設置しない固定床の再現計算を行い， 観測波形と計算波形の比較から水路部の粗度係数を 0.012と同定した. なお，表-1の各ケースのうち，数值計 算から算出した最大シールズ数は6〜7程度であった。

\section{(3) 再現計算結果}

\section{a) 移動床における地形・水位の再現}

表-1のケース3を例として，実験と計算における堤体 法先の容量式波高計（H2）の時系列水位を図-5，時系 列の堤体形状を図-6に示す。図-5の水位比較では津波到 達初期を除き波形は概ね一致している。実験では計算に 比べ到達が早くなっており，鴨原・今村 ${ }^{11)} の$ 検討と同様 の傾向にある.この要因は現時点で特定できておらず今 後の課題であるが，鉛直方向の流速分布を一定（長波近 似）として与えていることが影響している可能性がある

図-6の地形変化の比較では，実験では表法・裏法の両 方で侵食が生じているのに対し，計算では表法面のみで 侵食が生じている.これは，図-2で示したように実験で は堤体越流初期は表側も射流であったのに対し，計算で は表側は常流として表現されるためである．堤体の表側 の侵食を計算で表現するためには，常流・射流を精度よ く計算できる手法を用いる必要があることが把握できた.

\section{b) 堤体の侵食面積の比較}

表-1の各ケースについて，実験と計算の侵食面積の比 率の比較を図-7に示す。この比較検討時には，砂の堤体

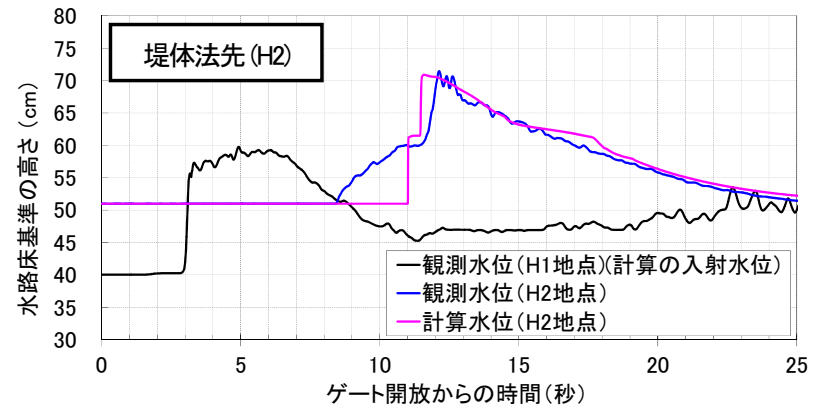

図-5 実験と計算の時系列の水位比較（ケース3の例）

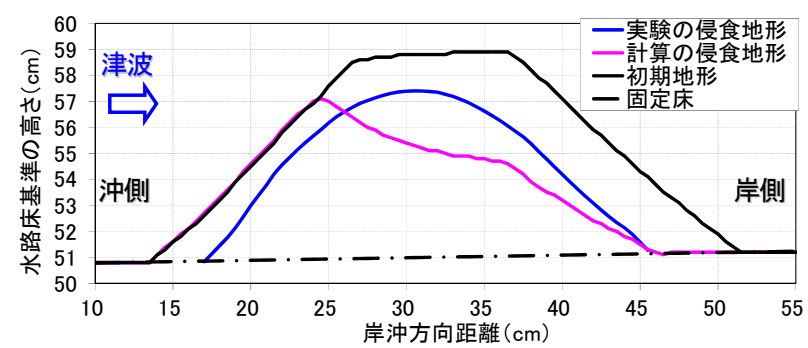

図-6 実験と計算の時系列の堤体形状比較（ケース3の例）

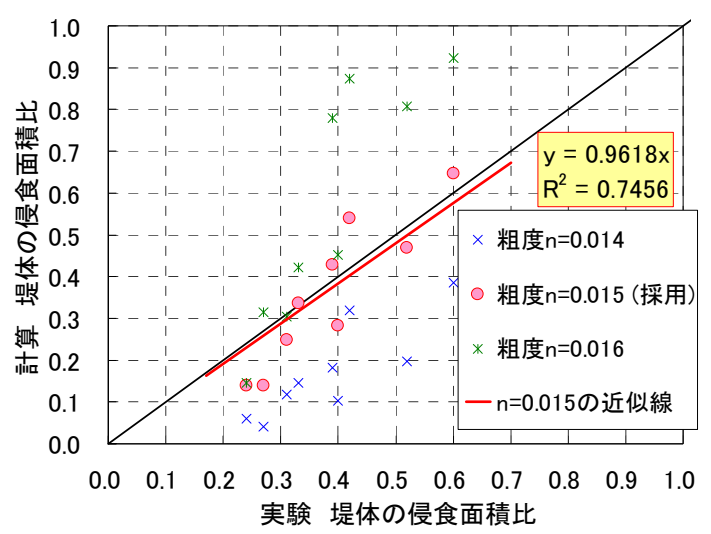

図-7 実験と計算における侵食面積の比較（ケース1９）

部の粗度係数を $0.014,0.015,0.016$ に変化させた.

津波越流時の表側の侵食については，平面二次元非線 形長波を基礎方程式とする流体解析では表現しきれなか ったものの, 粗度係数等の適切なパラメータの設定によ り堤体形状の侵食面積は実験と概ね同程度に調整できる ことが確認できた，ただし，表法の侵食を再現するため には，流体の流れを精度良く求めることなどが必要であ り，これらは今後の課題といえる.

\section{4. 砂丘侵食シミュレーションの現地適用}

実験スケールが影響しない現地海岸において，3.で構 築した平面二次元の津波移動床モデルを用いて土砂移動 計算を実施し，砂丘の侵食特性等を把握する.

\section{(1) 対象領域}

対象領域は，静岡県浜松市の中田島砂丘周辺とした. なお，当地域は，T.P.+13 m程度の防潮堤整備が進められ ている ${ }^{12)}$ が，本検討はこの防潮堤の整備前を想定した. 
表-3 計算条件一覧

\begin{tabular}{l|l|l}
\hline \multicolumn{1}{c|}{ 項目 } & \multicolumn{1}{|c}{ 設定 } & \multicolumn{1}{c}{ 備考 } \\
\hline 対象津波 & 南海トラフの巨大 & 対象地域の最大ク \\
& 地震ケース01 & ラスの津波 \\
\hline \multirow{2}{*}{ 格子間隔 } & $2430 \mathrm{~m}, 810 \mathrm{~m}, 270 \mathrm{~m}$, & 6領域でネスティン \\
& $90 \mathrm{~m}, 30 \mathrm{~m}, 10 \mathrm{~m}$ & グ \\
\hline 潮位 & T.P.+0.61 m & 朔望平均満潮位 \\
\hline 計算時間 & 6時間 & \\
\hline 砂の粒径 & $0.29 \mathrm{~mm}$ (中央粒径) & Junaidi ${ }^{14}$ らより設定 \\
\hline 砂の密度 & $2,600 \mathrm{~kg} / \mathrm{m} 3$ & \\
\hline 構造物 & 越流時に破壊 & 海岸・河川堤防等 \\
\hline
\end{tabular}

\section{(2) 検討条件}

検討条件一覧を表-3に示寸。計算に用いる地形，堤防， 粗度, 地盤変動量は, 内閣府 ${ }^{13)}$ が公表しているものを基 本とした．なお，砂丘表面には植生が被覆している場合 もあるが，本検討では簡単のため植生による耐侵食性は 考慮していない.

\section{(3) 検討結果}

中田島砂丘沖（T.P.-10 m）での時系列水位を図-8, 津 波前後の地形および地形変化量の平面分布を図-9, 時系 列の地形・水位の断面分布を図-10に示す，当地域には， 地震発生から20分後程度にT.P.+9 m程度の大きな津波が 到達寸る. 以降の津波水位は比較的小さいため, この地 震発生から20～25分程度の津波によって大きく地形が変

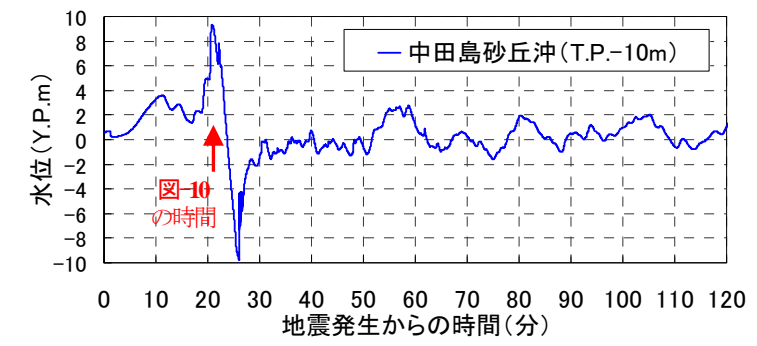

図-8 時系列水位（移動床計算）
化することとなる．海域および砂丘周辺では侵食してお り, 汀線付近は堆積している. 断面Aの中田島砂丘は, 高さが高いうえ堤体の幅が広いため，比較的小さな侵食 となる。一方，断面Bの2線堤形状の砂丘は，岸側砂丘 は1〜2分間程度の越流でT.P.+3 m程度まで侵食したが， 沖側砂丘は大きく侵食したもののT.P.+6 m程度まで残存 した. 岸側と沖側の両砂丘の違いは特に堤体幅であり， 堤体幅が砂丘侵食に対して耐侵食性を有することが把握 できた.

また，地形変化を考慮しない場合（固定床計算）と地 形変化を考慮する場合（移動床計算）の最大浸水深およ びその差分を図-11に示す，移動床計算の場合は，砂丘 等の地形変化が生じ，堤内地一津波が流入しやすくなる ため，浸水深および浸水面積が増大寸ることとなる．浸 水面積は，木造建物の全面破壊の基準值である浸水深2 m以上の面積が約1.5倍増加している. 国や自治体の津波 浸水想定では，地形変化を考慮しない固定床計算が一般 的に行われているが，実際の津波では地形変化が生じ，
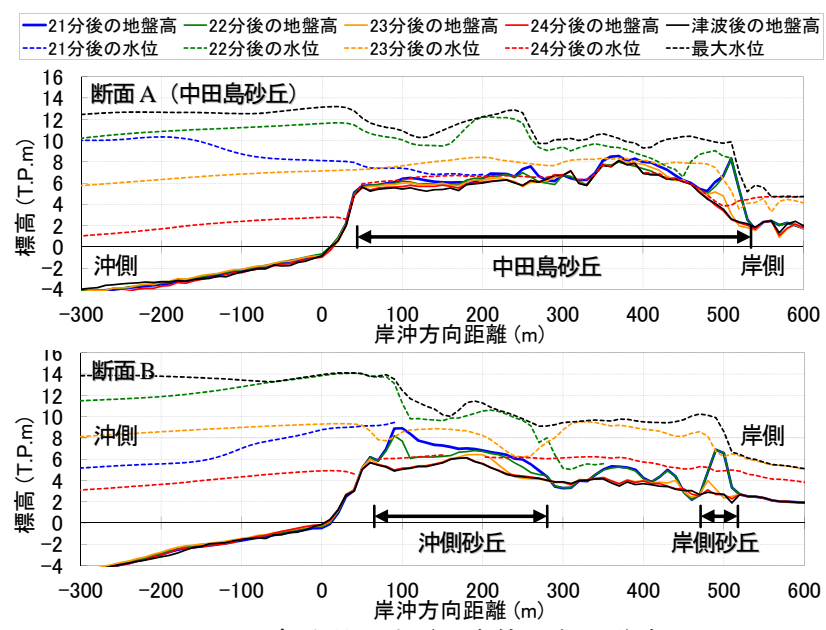

図-10 時系列の地形・水位の断面分布
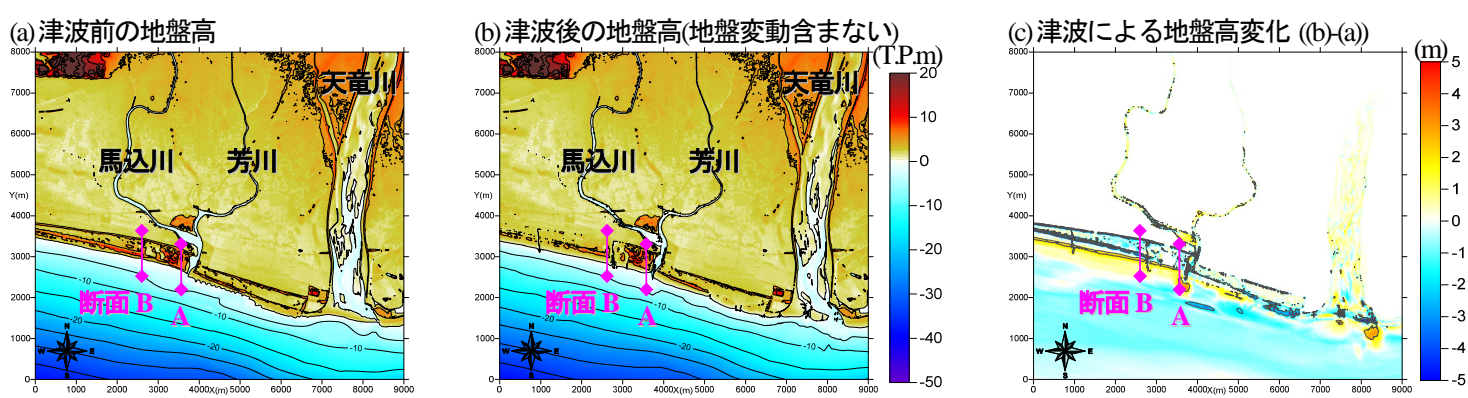

図-9 移動床計算による津波前後の地盤高および津波による地盤高変化

(a) 固定床計算の浸水深

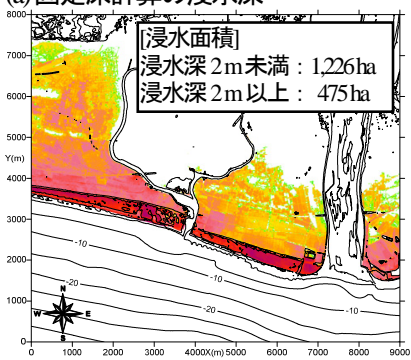

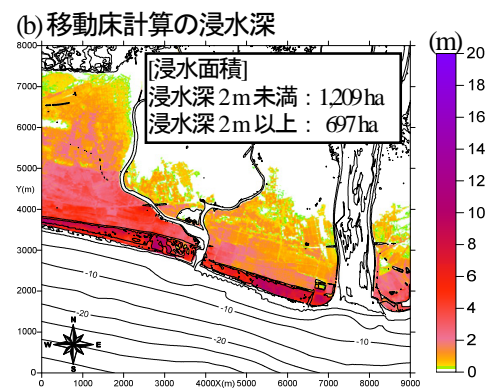

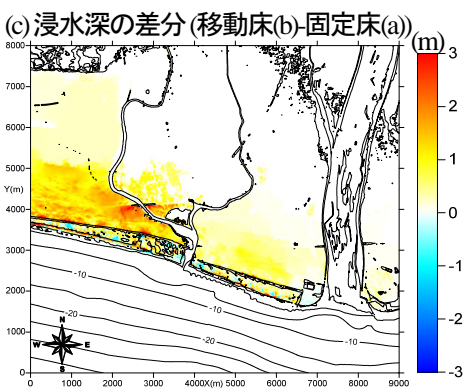

図-11 固定床計算・移動床計算の浸水深とその差分 
それに伴い津波が堤内地に浸水しやすくなる．当地域は 平野部に砂丘がある地形のため, 移動床・固定床計算に よる浸水被害の違いが生じや寸いものの，固定床計算は， 浸水被害を過小に評価している恐れがあるといえる.

\section{5. おわりに}

本研究では，ダムブレイク型造波による砂丘の侵食実 験およびその再現計算から，侵食特性の把握および聿波 移動床計算の適用性を検討した. また, 中田島砂丘周辺 を対象とした津波シミュレーションを行い，現地海岸の 砂丘の侵食特性を検討した. 以下に主な結果を示す.

(1) 侵食実験では，津波越流初期は堤体表側の流れが射 流であるが，時間の経過とともに常流に遷移し，その 流れに応じて堤体の侵食位置が表側から裏側一遷移し た. 天端高さの侵食速度は，越流水深で表現できる可 能性を示した. また，平面二次元の津波移動床計算に よる再現では，表側の流れが射流として越流する現象 を表現しきれないため堤体表側の侵食を再現できない ものの, 適切なパラメータ設定により堤体の侵食面積 は概ね再現できた。

(2) 中田島砂丘周辺における津波移動床計算では，南海 トラフの巨大地震により砂丘は大きく侵食されるもの の，砂丘の堤体幅が大きければ津波越流に対して耐侵 食性を有することが把握できた。また，固定床計算は， 移動床計算と比べ浸水被害を過小に評価する可能性が 示唆された.

\section{参考文献}

1) 前川俊明, 二瓶泰雄, 中田遥香 : 海岸砂丘・盛土に よる津波減災効果の検討, 土木学会論文集 B1(水工 学), Vol.69, No.4, pp.I_1453-I_1458, 2013.

2) 栁沢舞美, 二瓶泰雄, 山口晋平, 川邊翔平, 龍岡文 夫 : 海岸砂丘と補強盛土技術を組み合わせた新形式 防潮堤の提案, 土木学会論文集 B2 (海岸工学) Vol. 68, No.2, pp.I_886-I_890, 2012.

3) 二階堂竜司, 青木伸一, 加藤茂, 岡辺拓巳 : 津波越 流時の砂丘・盛土の侵食機構に関する研究，土木学
会論文集 B3（海洋開発）, Vol.71, No.2, pp.I_425I_430, 2015.

4) 山下啓, 菅原大助, 高橋智幸, 今村文彦, 今任嘉幸, 甲斐恭, 上原均, 加藤季広, 中田一人, 坂良太郎, 西川朝雄 : 岩手県陸前高田市における 2011 年東北地 方太平洋沖地震津波による大規模土砂移動の再現計 算, 土木学会論文集 B2（海岸工学）, Vol. 71, No.2, pp.I_499-I_504, 2015.

5) 今井健太郎, 菅原大助, 高橋智幸, 岩間俊二, 田中 仁：2011 年東北津波における北上川河口部の大規模 洗掘・堆積に関する数值的検討, 土木学会論文集 B2 (海岸工学)，Vol.71, No.2, pp.I_247-I_252, 2015.

6) 下園武範, 佐藤㯖司, 田島芳満：津波による砂堆の 侵食に関する研究, 海岸工学論文集, 第 54 巻, pp.511515, 2007.

7) 常田賢一, 竜田尚希, 谷本隆介, 鈴木啓祐：津波防 潮堤の評価および防潮盛土の耐侵食性の確保・向上, Vol.69, No.2, pp.I_1016-I_1020, 2013.

8) 邵小敏, 田中仁, 首藤伸夫 : 越流による砂州崩壊に 関する研究, 土木学会論文集, No.479, II -25, pp.31-40, 1993.

9) 池野正明, 吉井匠, 松山昌史, 藤井直樹 : 津波によ る砂移動量実験と浮遊砂巻上量式の提案, 電力中央 研究所研究報告 V08064, pp.17,28-29, 2009.

10) 土木学会水理委員会：水理公式集［平成 11 年版］, p.89, 社団法人土木学会, 1999.

11）鴨原良典, 今村文彦：陽解法による新しい非線形分 散波理論の津波数值計算法の提案, 土木学会東北支 部技術研究発表会（平成 15 年度），pp.144-145， 2003.

12) 静岡県: 浜松市沿岸域 防潮堤整備事業〜オール浜松 でやらまいか!〜， https://www.pref.shizuoka.jp/kensetsu/ke890/bouchoutei/gaiyo/index.html, 参照 2016-05-14.

13) 内閣府 : 南海トラフの巨大地震モデル検討会, 南海 トラフの巨大地震モデル検討会において検討された 震度分布・浸水域等に係るデータ提供について, http://www.bousai.go.jp/jishin/nankai/model/data_teikyou. html, 参照 2016-05-14.

14) Junaidi, 青木伸一, 加藤茂, 片岡三枝子, 若江直人, 尼崎貴大: 中田島砂丘における飛砂の特性と短期的 地形変化に関する研究, 土木学会論文集 B2（海岸工 学) Vol. 65, No.1, pp.I_621-I_625, 2009.

(2016.3.16 受付)

\title{
EROSION MECHANISUMS OF COASTAL DUNES USING HYDRAULIC MODEL TEST AND NUMERICAL SIMULATION
}

\author{
Ryuji NIKAIDO, Shin-ichi AOKI, Susumu ARAKI, \\ Ken-ichi TOKIDA and MUHAJJIR
}

This study investigated erosion mechanisms of coastal dunes through hydraulic model tests and numerical simulations. In the case of hydraulic model tests, the eroded portion of the dune depends on the regime of tsunami overflow. Seaward and landward slope was eroded by supercritical flow. In contrast, landward side was remarkably eroded by subcritical flow. In reproduction simulation of the hydraulic model test, eroded area was roughly matched by adjusting the parameters. Numerical simulation of topographic change of Nakatajima dune, which has a large crown width shows resistance to the erosion by tsunami overflow. 